\title{
Hyaluronic Acid Gel as an Outer Ear Canal Packing Following Tympanoplasty: A Randomized Controlled Study
}

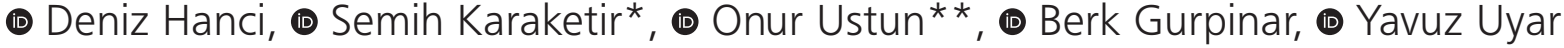 \\ University of Health Sciences Turkey, Prof. Dr. Cemil Tascioglou City Hospital, Clinic of Otorhinolaryngology, Istanbul, Turkey \\ ${ }^{*}$ Bulanik State Hospital, Clinic of Otorhinolaryngology, Mus, Turkey \\ ** University of Health Sciences Turkey, Haseki Training and Research Hospital, Clinic of Otorhinolaryngology, Istanbul, Turkey
}

\section{Abstract}

\begin{abstract}
Aim: In search of better alternative material than gelatin sponge dressing (GSD) traditionally used in the external ear canal after tympanoplasty, it's aimed to evaluate the use of new cross-linked hyaluronic acid gel (HYA) and compare it with GSD.

Methods: This block-randomized controlled trial was performed in 50 patients who underwent tympanoplasty between April and December 2019. The patients were divided into two groups according to external ear filling material (HYA as study group n=25, GSD as control group $n=25$ ). The groups were compared in terms of edema, pain, graft morphology, epithelization, drainage parameters at postoperative $1^{\text {st }}, 2^{\text {nd }}, 3^{\text {rd }}$, and $4^{\text {th }}$ weeks. In addition, pure-tone audiometry and graft success were also evaluated.

Results: After the first week, edema in HYA was significantly less than GSD ( $p=0.033)$. Reaching the $2^{\text {nd }}$ week, less discharge was observed in HYA ( $p=0.007)$. Third week results showed edema in HYA was significantly less than that of GSD ( $p=0.023)$. In the $4^{\text {th }}$ week, the postoperative gap gain in the HYA group was significantly higher than GSD $(p=0.037)$. The difference in graft intake between groups was not significant ( $p=0.189)$.
\end{abstract}

Conclusion: New cross-linked HYA gel may act as a promoter in the healing process after tympanoplasty and may have positive effects on hearing restoration.

Keywords: Hyaluronic acid, gelatin, tympanoplasty, ear canal

\section{Introduction}

Tympanic membrane perforation is one of the main causes of conductive hearing loss (1). Perforations often heal spontaneously to a greater extent requiring no further surgical intervention. Surgical repair of the tympanic membrane is a safe and proven method in susceptible cases. The success of the operation depends on the integrity of the tympanic membrane graft, maintaining adequate ventilation of the tympanum and dry ear with improved or at least preserved hearing function. Beyond high success rates, that operation possesses some complications such as graft medialization or lateralization, epithelialization problems in the external ear canal (EEC), stenosis, iatrogenic cholesteatoma; some of which may require further attention (2). To achieve good wound healing and graft integrity are the essentials to minimize complications. Therefore, absorbable and non-absorbable packing materials are used to support the graft and EEC and to prevent adhesions (3). Besides certain advantages, EEC packing reduces the quality of life and may provoke hypersensitivity reactions (4).

Hyaluronic acid (HYA) is a natural component of the extracellular matrix of body tissues. It stimulates the release of endogenous growth factors, epidermal growth factors, insulin growth factor, tumor necrosis factor and vascular endothelial growth factor (5). There are studies involving its use in myringoplasty (6), adhesive otitis media and mastoidectomy operations in otology $(7,8)$. Currently, several HYA products with different formulations are used

Address for Correspondence: Deniz Hanci, University of Health Sciences Turkey, Prof. Dr. Cemil Tascioglou City Hospital, Clinic of Otorhinolaryngology, Istanbul, Turkey Phone: +90 5323732866 E-mail: dhanci007@hotmail.com ORCID: orcid.org/0000-0002-6644-5059 Received: 04.01.2021 Accepted: 07.03.2021 
in otology (9). Recently, we acquired a new cross-linked HYA gel and began to use it in our clinical expertise; this product has a self cross-linked technology between HYA molecules. It is thought to have a controlled bioabsorption profile and the viscosity of the HYA is adapted to the critical tissue repair process. HYA leaves no potential space providing ease of application to the desired area. We, therefore, aimed to investigate the effects of this new molecule on EEC and graft after tympanoplasty operations.

\section{Methods}

\section{Study Design}

This study was approved by the ethics committee of Marmara University Faculty of Medicine (09.2019.199) and carried out in Prof. Dr. Cemil Tascioglu City Hospital. This randomized controlled study was performed on 50 ears of 50 patients between April and December 2019; cases were randomly and equally assigned either to HYA (PureRegen ${ }^{\circledR}$ Gel OTOL, BioRegen Biomedical Co. Ltd., Changzhou, China) or to gelatin sponge dressing group (GSD; Spongostan, Ethicon, New Jersey, USA). The GSD group was assigned as a control group and block randomization method was used for randomization. Informed consent was obtained from all patients. Inclusion criteria were chronic tympanic membrane perforation, age below sixty years, air-bone gap below $30 \mathrm{~dB}$ in pure tone audiometry and dry ear for at least the last 3 months. Exclusion criteria were previous ear surgery, smoking, diabetes, hypertension, ischemic heart disease, rheumatological disease or sinonasal pathology of any kind. The flow diagram of the study according to the Consolidated Standards of Reporting Trials (CONSORT) 2010 is presented in Figure 1.

\section{Operation Technique}

All surgeries were performed by the senior author (D.H.). All patients were operated under the condition of general anaesthesia through a retroauricular approach. A tragal island graft was prepared with a notch suitable for malleus insertion. After the underlay insertion of the harvested graft, the tympanic membrane and the outer ear was either filled with HYA or GSD randomly. A regimen of antibiotic therapy (ciprofloxacine $750 \mathrm{mg}$ BID) and non-steroidal anti-inflammatory drug (NSAID) treatment (etodolac $400 \mathrm{mg} \mathrm{BID),} \mathrm{was} \mathrm{applied} \mathrm{for} \mathrm{one} \mathrm{week} \mathrm{as} \mathrm{a}$ postoperative routine in our clinic. EEC dressing was opened on the $7^{\text {th }}$ day.

\section{Postoperative Follow-up}

The postoperative monitoring and controls were assessed by a different surgeon (B.G.). Weekly controls were made for one month postoperatively. Edema was scored as low in cases of swelling between $0 \%-25 \%$ of
EEC, moderate in 25\%-75\%, and high in more than $75 \%$. Pain is scored as Yes=pain requiring NSAIDs or $\mathrm{No}=$ pain not requiring NSAIDs. EEC epithelialization was classified as complete epithelialization, partial granulation or advanced granulation. Morphology of the graft was classified as pale, partially vascularized or completely vascularized. EEC discharge was noted and classified as discharge requiring topical antibiotics or discharge requiring topical and systemic antibiotics. On the postoperative $4^{\text {th }}$ week, a repeat pure tone audiometry was performed for each patient.

\section{Statistical Analysis}

Statistical analyses were performed using the SPSS software version 23 (IBM, Turkey). The variables were investigated using visual (histograms, probability plots) and analytical methods (Kolmogorov-Smirnov/Shapiro-Wilk's test) to determine the normal distribution. Descriptive analyses were presented as mean, standard deviations, median, minimum and maximum. Chi-square test or Fisher's Exact test was used to compare proportions in different groups. Mann-Whitney $U$ test and Student's t-tests were used to compare means in different groups. P-value less than 0.05 was accepted as statistically significant.

\section{Results}

Scores of the postoperative first week (Table 1) showed no significant difference between groups in terms of pain $(p=0.758)$ and discharge $(p=1.000)$. The graft morphology could not be evaluated microscopically due to EEC edema. The epithelization in HYA was faster than GSD ( $p=0.077)$. The edema in HYA was significantly less than GSD $(p=0.033)$. In the second week, both groups had less edema, pain, discharge and better epithelization compared to the first postoperative week. There was no significance among the two groups in terms of edema $(p=0.258)$, pain $(p=0.758)$ and graft morphology $(p=0.615)$. Epithelization in HYA was faster than GSD, but the scores were not statistically significant $(p=0.070)$. Complete epithelization was observed in $40 \%$ $(n=10)$ in HYA whereas $16 \%(n=4)$ in GSD. Significant less discharge was observed in HYA ( $p=0.007)$. The third week revealed less edema, pain, discharge, better epithelization and better graft morphology compared to the second postoperative week. No significance was found between the two groups in terms of pain $(p=0.508)$, discharge $(p=0.185)$ and graft morphology $(p=0.225)$. The edema in HYA was significantly less than GSD $(p=0.023) .60 \%$ $(n=15)$ HYA patients had no edema while it was $28 \%$ $(n=7)$ in GSD. The epithelization in HYA was significantly faster than GSD $(p=0.037)$. Complete epithelization was observed in $80 \%(n=20)$ HYA and 52\% (13) GSD. 


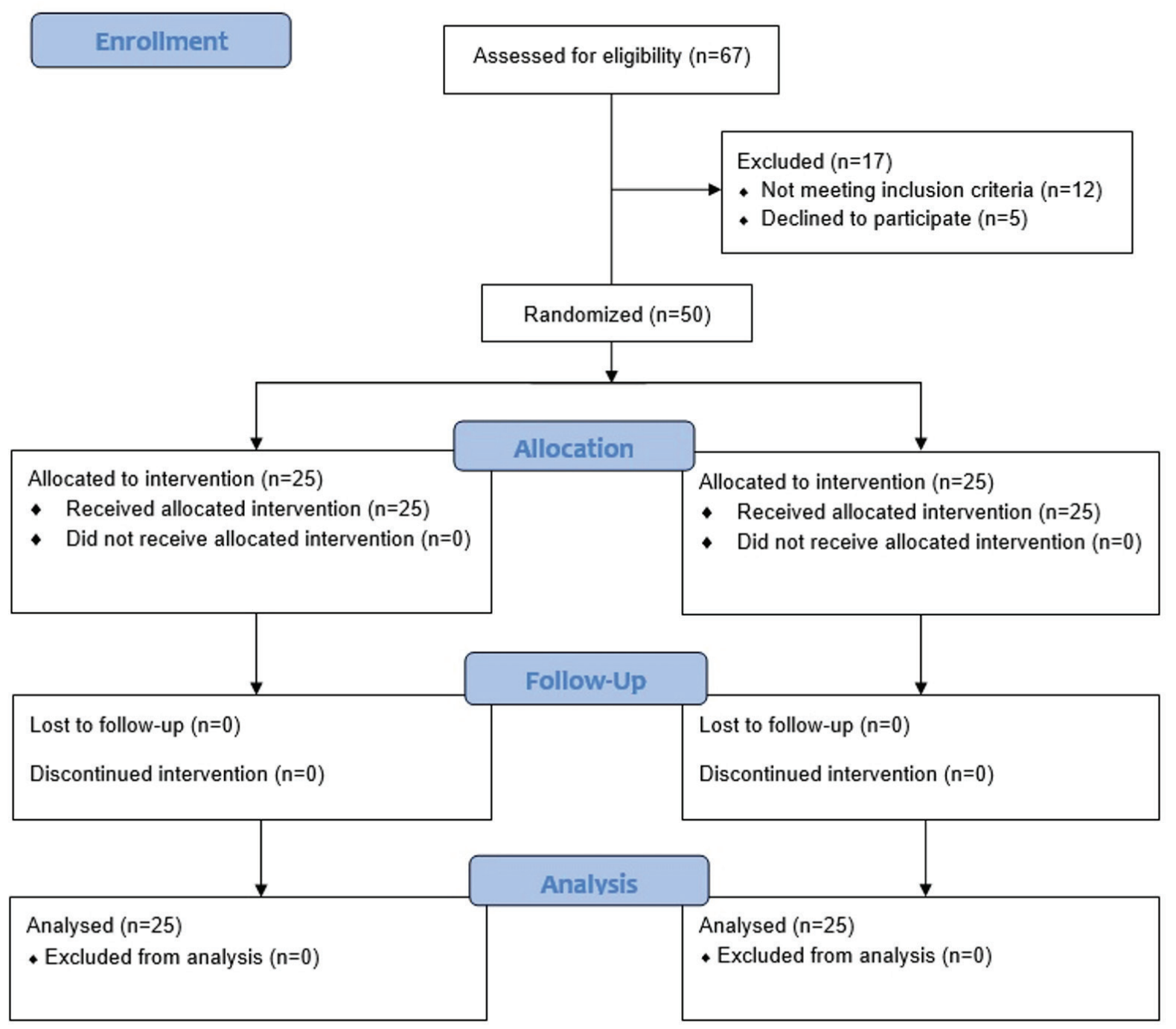

Figure 1. CONSORT 2010 flow diagram

The clinical outcomes on the postoperative fourth week showed that $100 \%(n=25)$ HYA had no edema nor pain and achieved complete epithelization of EEC while in GSD, $12 \%(n=3)$ had minimum edema, 16\% $(n=4)$ had partial granulation. Full vascularization was observed in $92 \%$ $(n=23)$ of HYA and $84 \%(n=21)$ of GSD.

The results of preoperative and postoperative firstmonth audiometry tests of both groups are shown in Table 2. Preoperative air conduction $(p=0.377)$ and bone conduction ( $p=0.143$ ) was not significant between the two groulps. Postoperative bone conduction was not significant between the two groups $(p=0.141)$. The difference in the postoperative air conduction between the two groups was also not significant but close to being significant $(p=0.070)$. The gap gain in HYA $(15.2 \pm 5.2 \mathrm{~dB})$ was significantly higher than GSD $(11 \pm 6.1 \mathrm{~dB})(p=0.037)$ (Table 2).
The success rate of graft in HYA was higher than the GSD. In HYA, the graft intake was successful in 24 patients $(96 \%)$ with one failure (4\%) only whereas in GSD the graft intake was successful in 20 patients (80\%) with five failure (20\%). Graft intake between groups was not significant $(p=0.189)$.

\section{Discussion}

It is a routine to fill the EEC with absorbable/nonabsorbable materials in order to prevent ear canal deformity or EEC stenosis at the end of ear surgery. However, the risk of displacement of the graft still remains during the insertion and removal of the packing material. Non-absorbable materials include ear-wick, silastic sheet or gauze with ointments. Absorbable materials can be in the form of gelatin sponge (Spongostan) or Tri-Adcortyl/ Polyfax ointment. Absorbable materials are usually 


\begin{tabular}{|c|c|c|c|c|c|c|c|c|c|c|c|c|c|}
\hline & & \multicolumn{3}{|c|}{ Postoperative first week } & \multicolumn{3}{|c|}{$\begin{array}{l}\text { Postoperative second } \\
\text { week }\end{array}$} & \multicolumn{3}{|c|}{ Postoperative third week } & \multicolumn{3}{|c|}{$\begin{array}{l}\text { Postoperative fourth } \\
\text { week }\end{array}$} \\
\hline & & \multirow{2}{*}{$\begin{array}{l}\text { HYA } \\
(n=25)\end{array}$} & \multirow{2}{*}{$\begin{array}{l}\text { GSD } \\
(n=25)\end{array}$} & \multirow{2}{*}{$\mathbf{p}^{a}$} & \multirow{2}{*}{$\begin{array}{l}\text { HYA } \\
(n=25)\end{array}$} & \multirow{2}{*}{$\begin{array}{l}\text { GSD } \\
(n=25)\end{array}$} & \multirow{2}{*}{$\mathbf{p}^{\alpha}$} & \multirow{2}{*}{$\begin{array}{l}\text { HYA } \\
(n=25)\end{array}$} & \multirow{2}{*}{$\begin{array}{l}\text { GSD } \\
(n=25)\end{array}$} & \multirow{2}{*}{$\mathbf{p}^{\alpha}$} & \multirow{2}{*}{$\begin{array}{l}\text { HYA } \\
(n=25)\end{array}$} & \multirow{2}{*}{$\begin{array}{l}\text { GSD } \\
(n=25)\end{array}$} & \multirow{2}{*}{$\mathbf{p}^{a}$} \\
\hline & & & & & & & & & & & & & \\
\hline \multirow[t]{5}{*}{ Edema } & - & - & - & $0.033^{*}$ & - & - & 0.258 & - & - & $0.023^{*}$ & - & - & 0.235 \\
\hline & No & $0(0 \%)$ & $0(0 \%)$ & - & $1(4 \%)$ & $0(0 \%)$ & - & $\begin{array}{l}15 \\
(60 \%)\end{array}$ & $\begin{array}{l}7 \\
(28 \%)\end{array}$ & - & $\begin{array}{l}25 \\
(100 \%)\end{array}$ & $\begin{array}{l}22 \\
(88 \%)\end{array}$ & - \\
\hline & Low & $\begin{array}{l}8 \\
(32 \%)\end{array}$ & $1(4 \%)$ & - & $\begin{array}{l}14 \\
(56 \%)\end{array}$ & $\begin{array}{l}10 \\
(40 \%)\end{array}$ & - & $\begin{array}{l}10 \\
(40 \%)\end{array}$ & $\begin{array}{l}18 \\
(72 \%)\end{array}$ & - & $0(0 \%)$ & $3(12 \%)$ & - \\
\hline & Moderate & $\begin{array}{l}11 \\
(44 \%)\end{array}$ & $\begin{array}{l}13 \\
(52 \%) \\
\end{array}$ & - & $\begin{array}{l}10 \\
(40 \%)\end{array}$ & $\begin{array}{l}15 \\
(60 \%)\end{array}$ & - & $0(0 \%)$ & $0(0 \%)$ & - & $0(0 \%)$ & $0(0 \%)$ & - \\
\hline & High & $\begin{array}{l}6 \\
(24 \%)\end{array}$ & $\begin{array}{l}11 \\
(44 \%)\end{array}$ & - & $0(0 \%)$ & $0(0 \%)$ & - & $0(0 \%)$ & $0(0 \%)$ & - & $0(0 \%)$ & $0(0 \%)$ & - \\
\hline \multirow[t]{4}{*}{ Pain } & - & - & - & 0.758 & - & - & 0.758 & - & - & 0.508 & - & - & 1.000 \\
\hline & No & $0(0 \%)$ & $0(0 \%)$ & - & $\begin{array}{l}6 \\
(24 \%)\end{array}$ & $\begin{array}{l}6 \\
(24 \%)\end{array}$ & - & $\begin{array}{l}20 \\
(80 \%)\end{array}$ & $\begin{array}{l}18 \\
(72 \%)\end{array}$ & - & $\begin{array}{l}25 \\
(100 \%)\end{array}$ & $\begin{array}{l}25 \\
(100 \%)\end{array}$ & - \\
\hline & $\begin{array}{l}\text { Yes (no } \\
\text { NSAID) }\end{array}$ & $\begin{array}{l}17 \\
(68 \%)\end{array}$ & $\begin{array}{l}18 \\
(72 \%)\end{array}$ & - & $1(4 \%)$ & $\begin{array}{l}5 \\
(20 \%)\end{array}$ & - & $0(0 \%)$ & $0(0 \%)$ & - & $0(0 \%)$ & $0(0 \%)$ & - \\
\hline & $\begin{array}{l}\text { Yes (requiring } \\
\text { NSAID) }\end{array}$ & $\begin{array}{l}8 \\
(32 \%)\end{array}$ & $\begin{array}{l}7 \\
(28 \%)\end{array}$ & - & $\begin{array}{l}18 \\
(72 \%)\end{array}$ & $\begin{array}{l}14 \\
(56 \%)\end{array}$ & - & $\begin{array}{l}5 \\
(20 \%)\end{array}$ & $\begin{array}{l}7 \\
(28 \%) \\
\end{array}$ & - & $0(0 \%)$ & $0(0 \%)$ & - \\
\hline \multirow[t]{4}{*}{ Discharge } & - & - & - & 1.000 & - & - & $0.007^{*}$ & - & - & 0.185 & - & - & 0.667 \\
\hline & Dry & $0(0 \%)$ & $0(0 \%)$ & - & $\begin{array}{l}13 \\
(52 \%)\end{array}$ & $\begin{array}{l}4 \\
(16 \%)\end{array}$ & - & $\begin{array}{l}21 \\
(84 \%)\end{array}$ & $\begin{array}{l}17 \\
(68 \%)\end{array}$ & - & $\begin{array}{l}23 \\
(92 \%) \\
\end{array}$ & $\begin{array}{l}21 \\
(84 \%)\end{array}$ & - \\
\hline & $\begin{array}{l}\text { Topical } \\
\text { antibiotic }\end{array}$ & $\begin{array}{l}18 \\
(72 \%)\end{array}$ & $\begin{array}{l}18 \\
(72 \%)\end{array}$ & - & $\begin{array}{l}12 \\
(48 \%)\end{array}$ & $\begin{array}{l}21 \\
(84 \%)\end{array}$ & - & $\begin{array}{l}4 \\
(16 \%)\end{array}$ & $\begin{array}{l}8 \\
(32 \%)\end{array}$ & - & $2(8 \%)$ & $4(16 \%)$ & - \\
\hline & $\begin{array}{l}\text { Oral + topical } \\
\text { antibiotic }\end{array}$ & $\begin{array}{l}7 \\
(28 \%)\end{array}$ & $\begin{array}{l}7 \\
(28 \%)\end{array}$ & - & $0(0 \%)$ & $0(0 \%)$ & - & $0(0 \%)$ & $0(0 \%)$ & - & $0(0 \%)$ & $0(0 \%)$ & - \\
\hline \multirow[t]{4}{*}{ Epithelization } & - & - & - & 0.077 & - & - & 0.070 & - & - & $0.037^{*}$ & - & - & 0.110 \\
\hline & Complete & $0(0 \%)$ & $0(0 \%)$ & - & $\begin{array}{l}10 \\
(40 \%)\end{array}$ & $\begin{array}{l}4 \\
(16 \%)\end{array}$ & - & $\begin{array}{l}20 \\
(80 \%)\end{array}$ & $\begin{array}{l}13 \\
(52 \%)\end{array}$ & - & $\begin{array}{l}25 \\
(100 \%)\end{array}$ & $\begin{array}{l}21 \\
(84 \%)\end{array}$ & - \\
\hline & $\begin{array}{l}\text { Granulation } \\
\text { (partial) }\end{array}$ & $\begin{array}{l}19 \\
(76 \%)\end{array}$ & $\begin{array}{l}13 \\
(52 \%)\end{array}$ & - & $\begin{array}{l}15 \\
(60 \%)\end{array}$ & $\begin{array}{l}19 \\
(76 \%)\end{array}$ & - & $\begin{array}{l}5 \\
(20 \%)\end{array}$ & $\begin{array}{l}12 \\
(48 \%)\end{array}$ & - & $0(0 \%)$ & $4(16 \%)$ & - \\
\hline & $\begin{array}{l}\text { Granulation } \\
\text { (advanced) }\end{array}$ & $\begin{array}{l}6 \\
(24 \%) \\
\end{array}$ & $\begin{array}{l}12 \\
(48 \%) \\
\end{array}$ & - & $0(0 \%)$ & $2(8 \%)$ & - & $0(0 \%)$ & $0(0 \%)$ & - & $0(0 \%)$ & $0(0 \%)$ & - \\
\hline \multirow[t]{4}{*}{$\begin{array}{l}\text { Graft } \\
\text { morphology }\end{array}$} & - & - & - & - & - & - & 0.615 & - & - & 0.225 & - & - & 0.667 \\
\hline & $\begin{array}{l}\text { Full } \\
\text { vascularization }\end{array}$ & - & - & - & $\begin{array}{l}4 \\
(16 \%)\end{array}$ & $\begin{array}{l}4 \\
(16 \%)\end{array}$ & - & $\begin{array}{l}19 \\
(76 \%)\end{array}$ & $\begin{array}{l}15 \\
(60 \%)\end{array}$ & - & $\begin{array}{l}23 \\
(92 \%) \\
\end{array}$ & $\begin{array}{l}21 \\
(84 \%)\end{array}$ & - \\
\hline & $\begin{array}{l}\text { Partial } \\
\text { vascularization }\end{array}$ & - & - & - & $\begin{array}{l}17 \\
(68 \%)\end{array}$ & $\begin{array}{l}14 \\
(56 \%)\end{array}$ & - & $\begin{array}{l}6 \\
(24 \%)\end{array}$ & $\begin{array}{l}10 \\
(40 \%)\end{array}$ & - & $2(8 \%)$ & $4(16 \%)$ & - \\
\hline & Pale & - & - & - & $\begin{array}{l}4 \\
(16 \%)\end{array}$ & $\begin{array}{l}7 \\
(28 \%)\end{array}$ & - & $0(0 \%)$ & $0(0 \%)$ & - & $0(0 \%)$ & $0(0 \%)$ & - \\
\hline
\end{tabular}

removed within the first 2-3 weeks after surgery. This is an office procedure that requires no anaesthesia. However, non-absorbable materials often cause pain on removal and may displace the graft (10). Yazama et al. (11) evaluated retrospectively the factors affecting the postoperative hearing improvement in patients who underwent type IV tympanoplasty. They claimed that the packing material placed in the outer ear canal affected the postoperative hearing results. Hearing improvement in the shredded gauze group was significantly higher than the Spongel ${ }^{\circledR}$ group. In the present study, the postoperative gap gain in the HYA group is higher than in the GSD group.

HYA is found in the extracellular matrix of human tissue and is a natural polysaccharide. The main components are beta-glucuronic acid and N-acetyl-D glucosamine. It contributes considerably to viscoelastic properties and hydration regulation for soft tissue. HYA can be used safely and easily in clinical applications (12). HYA is advisable 


\begin{tabular}{|c|c|c|c|c|c|}
\hline & \multicolumn{2}{|l|}{$\begin{array}{l}\text { HYA } \\
(n=25)\end{array}$} & \multicolumn{2}{|l|}{$\begin{array}{l}\text { GSD } \\
(n=25)\end{array}$} & \multirow[t]{2}{*}{ p } \\
\hline & Mean \pm SD & $\begin{array}{l}\text { Median } \\
\text { (min-max) }\end{array}$ & Mean \pm SD & $\begin{array}{l}\text { Median } \\
\text { (min-max) }\end{array}$ & \\
\hline \multicolumn{6}{|c|}{ Air conduction $(\mathrm{dB})$} \\
\hline Preoperative & $32 \pm 5.3$ & $34(24-45)$ & $34 \pm 4.5$ & $35(26-42)$ & $0.377^{* *}$ \\
\hline Postoperative & $18 \pm 4.9$ & $16(12-28)$ & $22 \pm 6.9$ & $22(12-34)$ & 0.070 ** \\
\hline \multicolumn{6}{|c|}{ Bone conduction (dB) } \\
\hline Preoperative & $13 \pm 4.0$ & $13(6-20)$ & $11 \pm 3.4$ & $12(5-18)$ & $0.143^{* *}$ \\
\hline Postoperative & $13 \pm 4.0$ & $13(8-24)$ & $11 \pm 6.1$ & $11(2-24)$ & $0.141 * *$ \\
\hline Gap gain $(\mathrm{dB})$ & $15 \pm 5.2$ & $13(8-24)$ & $11 \pm 6.1$ & $11(2-24)$ & $0.037^{*}$ \\
\hline
\end{tabular}

in otology because of its non-inflammatory property. It provides a viscoelastic environment by holding water depending on its physical properties. Thus, it is thought to play a role in facilitating the healing of the fibrous layer by preventing dehydration (13). PureRegen ${ }^{\circledR}$ Gel OTOL is a new cross-linked HYA gel with controlled degradation and optimum viscosity designed for outer and middle ear surgery.

In our study, it was observed that the edema in the HYA group was significantly less in the first week. Histologically, edema is one of the main components of the inflammatory response that adversely affects wound healing. During the edema, microcirculation failure develops due to the pressure increase in the interstitial distance, thereby reducing wound site oxygenation and tissue nutrition. Accordingly, the exudate occurring at the wound site cannot be removed, which negatively affects wound healing and also prepares the ground for infection (14).

We also observed that the discharge in HYA was significantly lower in the second week. Abundant discharge may be the result of a decrease in general tissue oxygenation and the accumulation of uncleaned exudate that occurs with edema. Additionally, excess topical ciprofloxacin may impede the regeneration of the tympanic membrane (15). On the other hand, there are data reporting that HYA prevents biofilm formation. Bacterial colonization can also be blocked with an inhibitor that interferes with ligand-receptor interaction for bacterial binding. One of these inhibitors is HYA (16).

Epithelization at the $3^{\text {rd }}$ week in HYA was completed earlier in our study. Martini et al. (8) also reported that reepithelialization and graft properties were better in HYA. Studies have shown that HYA stimulates growth factors such as endogenous growth factor, tumor necrosis factor, insulin growth factor, vascular endothelial growth factor (5). Also, it has been reported that these factors stimulate revascularization, cell growth and differentiation in the healing process of the tympanic membrane (17). HYA is frequently used in tympanic membrane perforations due to this feature. Alhabib et al. (6) compared the effectiveness of platelet-rich plasma (PRP) and HYA in patients with fat myringoplasty. Graft success was statistically significant in the HYA group. In our study, although graft success was higher in HYA, this difference was not statistically significant. We believe, if the number of patients was more, our results could be positive in favor of HYA.

\section{Study Limitation}

The most important limitation of the study is that some of the parameters examined and compared postoperatively are based on subjective evaluation. In addition, there is a need for a study with more participants.

\section{Conclusion}

An ideal EEC packing should stabilize flaps by taking the shape of EEC, do not cause infection, accelerate healing and provide patient comfort. The use of new cross-linked HYA gel for packing after ear surgery meets these expectations as well as providing patient comfort.

\section{Authorship Contributions}

Concept: D.H., S.K., O.U., B.G., Y.U., Design: D.H., S.K., O.U., B.G., Y.U., Data Collection or Processing: D.H., S.K., O.U., B.G., Y.U., Analysis or Interpretation: D.H., S.K., O.U., B.G., Y.U., Literature Search: D.H., S.K., O.U., B.G., Y.U., Writing: D.H., S.K., O.U., B.G., Y.U.,

Conflict of Interest: No conflict of interest was declared by the authors.

Financial Disclosure: The authors declared that this study received no financial support.

\section{References}

1. Amoils $C P$, Jackler RK, Lustig LR. Repair of chronic tympanic membrane perforations using epidermal growth factor. Otolaryngol Head Neck Surg 1992;107:669-83. 
2. Caye-Thomasen $P$, Nielsen TR, Tos M. Bilateral myringoplasty in chronic otitis media. Laryngoscope 2007;117:903-6.

3. Tos M. Packs, Wicks, Inserts and Stents. In: Manual of Middle Ear Surgery. New York: Thieme Medical Publishers, Inc.; 1997;3:168-76.

4. Bennett AM, Bartle J, Yung MW. Avoidance of BIPP allergy hypersensitivity reactions following ear surgery. Clin Otolaryngol 2008;33:32-4.

5. Saliba I, Alzahrani M, Zhu T, Chemtob S. Growth factors expression in hyaluronic acid fat graft myringoplasty. Laryngoscope 2014;124:224-30.

6. Alhabib SF, Saliba I. Hyaluronic Acid Fat Graft Myringoplasty Versus Autologous Platelet Rich Plasma. J Clin Med Res 2017;9:30-4.

7. Deng R, Fang $Y$, Shen J, et al. Effect of esterified hyaluronic acid as middle ear packing in tympanoplasty for adhesive otitis media. Acta Otolaryngol 2018;138:105-9.

8. Martini A, Morra B, Aimoni C, Radice M. Use of a hyaluronan-based biomembrane in the treatment of chronic cholesteatomatous otitis media. Am J Otol 2000;21:468-73.

9. Abi Zeid Daou C, Bassim M. Hyaluronic acid in otology: Its uses, advantages and drawbacks - A review. Am J Otolaryngol 2020;41:102375.

10. Zeitoun H, Sandhu GS, Kuo M, Macnamara M. A randomized prospective trial to compare four different ear packs following permeatal middle ear surgery. J Laryngol Otol 1998;112:1404.
11. Yazama H, Watanabe T, Fujiwara K, Takeuchi $H$. Factors Affecting Postoperative Hearing Results in Type IV Tympanoplasty: Preliminary Study of the Influence of External Auditory Canal Packing Material. Yonago Acta Med 2020;63:313-8.

12. Jang $\mathrm{CH}$, Park $\mathrm{H}, \mathrm{Cho} \mathrm{YB}$, Choi $\mathrm{CH}$. The effect of anti-adhesive packing agents in the middle ear of guinea pig. Int J Pediatr Otorhinolaryngol 2008;72:1603-8.

13. Güneri EA, Tekin S, Yilmaz O, ve ark. The effects of hyaluronic acid, epidermal growth factor, and mitomycin in an experimental model of acute traumatic tympanic membrane perforation. Otol Neurotol 2003;24:371-6.

14. Andersen DK. (ed.) Master Series in Surgery: Advances in Wound Healing and Tissue Repair. New York: World Medical Press 1993.

15. Hebda PA, Yuksel S, Dohar JE. Effects of ciprofloxacindexamethasone on myringotomy wound healing. Laryngoscope 2007;117:522-8.

16. Romanò $\mathrm{CL}$, De Vecchi $\mathrm{E}$, Bortolin M, Morelli I, Drago L. Hyaluronic Acid and Its Composites as a Local Antimicrobial/ Antiadhesive Barrier. J Bone Jt Infect 2017;2:63-72.

17. Hakuba N, Iwanaga M, Tanaka S, et al. Basic fibroblast growth factor combined with atelocollagen for closing chronic tympanic membrane perforations in 87 patients. Otol Neurotol 2010;31:118-21. 